\title{
A STUDY OF MERCHANDISE INFORMATION AND INTERFACE DESIGN ON B2C WEBSITES
}

\author{
Hui-Ming Kuo \\ Department of Logistics Management, Shu-Te University, Kaohsiung County, Taiwan, R.O.C. \\ Cheng-Wu Chen \\ Institute of Maritime Information and Technology, National Kaohsiung Marine University, Kaohsiung, Taiwan, R.O.C. \\ Department of Information Management, National Kaohsiung First University of Science and Technology, Kaohsiung \\ County, Taiwan, R.O.C., chengwu@mail.nkmu.edu.tw \\ Ching-Wen Chen \\ Department of Information Management, National Kaohsiung First University of Science and Technology, Kaohsiung \\ County, Taiwan, R.O.C.
}

Follow this and additional works at: https://jmstt.ntou.edu.tw/journal

Part of the Management Information Systems Commons

\section{Recommended Citation}

Kuo, Hui-Ming; Chen, Cheng-Wu; and Chen, Ching-Wen (2011) "A STUDY OF MERCHANDISE INFORMATION AND INTERFACE DESIGN ON B2C WEBSITES," Journal of Marine Science and Technology. Vol. 19: Iss. 1, Article 3.

DOI: $10.51400 / 2709-6998.2133$

Available at: https://jmstt.ntou.edu.tw/journal/vol19/iss1/3

This Research Article is brought to you for free and open access by Journal of Marine Science and Technology. It has been accepted for inclusion in Journal of Marine Science and Technology by an authorized editor of Journal of Marine Science and Technology. 


\section{A STUDY OF MERCHANDISE INFORMATION AND INTERFACE DESIGN ON B2C WEBSITES}

\section{Acknowledgements}

The authors would like to thank the National Science Council for financial support of this research under Contract No. NSC 96-2221-E-366-007- and NSC 98-2221-E-366-006-MY2. The authors are also most grateful for the kind assistance of Prof. Chee-Fai Yung, Editor-in-chief of Journal of Marine Science and Technology, and the constructive suggestions of the anonymous reviewers, all of which has led to the making of several corrections and suggestions that have greatly aided us in improving the presentation of this paper. 


\title{
A STUDY OF MERCHANDISE INFORMATION AND INTERFACE DESIGN ON B2C WEBSITES
}

\author{
Hui-Ming Kuo*, Cheng-Wu Chen**,***, and Ching-Wen Chen***
}

Key words: website information, supporting interface design, B2C, shopping.

\section{ABSTRACT}

The convenience of the Internet make online shopping an ever more attractive option for customers. The B2C websites are one of the most popular and rapidly developing types of Internet shopping sites. This market begin to attract the attention of both local and international businesses. However, the online purchase process is often complicated, and many customers have difficulty with or even fail to complete the process. Information about the merchandise and the interface design can have a big influence on this kind of problem. In this study, we evaluate the information offered and the interface design of the shopping websites with the goal of providing service and making the website easier for the customer to use. A behavioral model of the Internet customer is constructed as the structural basis of the examination. An evaluation form is also designed based on this model. This form is used to gather information on the interface design of 351 domestic and foreign shopping websites. Comparisons are made between the websites in relation to various aspects such as product category, procedural steps, and domestic/ foreign websites. The results show that there are significant differences between sites in terms of the way information and user interface design, at every step of the shopping process. There are also differences between domestic and foreign websites. The results can serve as useful reference for website owners and designers who want to provide consumers with more convenient and barrier-free shopping environments.

Paper submitted 08/13/09; revised 11/23/09; accepted 12/15/09. Author for correspondence: Cheng-Wu Chen (e-mail: chengwu@mail.nkmu.edu.tw)

*Department of Logistics Management, Shu-Te University, Kaohsiung County, Taiwan, R.O.C.

**Institute of Maritime Information and Technology, National Kaohsiung Marine University, Kaohsiung, Taiwan, R.O.C.

***Department of Information Management, National Kaohsiung First University of Science and Technology, Kaohsiung County, Taiwan, R.O.C.

\section{INTRODUCTION}

The convenience of online shopping and ready access to the Internet combine to give this market vast potential for growth. It has already become so important that no one dare ignore it. Both the frequency and depth of use of the Internet are increasing worldwide. We are gradually becoming dependent on Internet services for many daily activities, from email communication, browsing for information, to finding a mate through dating websites, entertainment and shopping. The growth of online shopping activities has been particularly rapid, presenting business opportunities, opening up a vast new territory, which business enterprises are eager to explore [3, 23].

According to one report published by Yam.com [30] in 2002 , even in the face of economic recession, online shopping continues to grow, making up even greater portions of the average annual consumption. According to investigation results published in 2004, online commerce has gained dramatically both in terms of the portion of the population who indulge in it and the amount the market is worth. The percentage of Internet users is about $66 \%$ the total population. The yearly average number of purchases made online is 5.7 per person. The average amount per instance is about NT $\$ 2,583$. Over $60 \%$ of Internet users say that they are willing to shop online over the next year. Another report by Taiwan's Institute for Information Industry points out that, along with increasing user dependency on the Internet, support activities related to logistics and cash flow are maturing. As a consequence, many stores are also setting up online outlets. The value of the online shopping market reached NT\$39,000,000,000 in 2004, a $61 \%$ growth over that in 2003. By 2005 and 2006, the growth rate had reached $50 \%$. The 2006 market size was expected to meet the goal of NT $\$ 90,000,000,000$. In the US, the percentage of Internet users who also shopped online exceeded $60 \%$ in 2004 with the value of the online shopping market reaching US $\$ 136,000,000,000$, a $31 \%$ growth compared with that in 2003. It was predicted that the transaction amount of e-commerce would reach US\$172,000,000,000 in 2005. This is $7.7 \%$ the transaction amount of the traditional physical retail market. The amount was expected to reach US\$328,000,000,000 in $2007,13 \%$ that of the traditional market. Between 2005 and 2010 , the average compound annual growth rate is predicted to 
reach 13\% [1]. The number of Internet users in Western Europe has also been climbing rapidly. In 2004, the size of the online shopping market reached EU $\$ 41,100,000,000$, and was expected to reach EU\$78,600,000,000 by 2007. From 2004 to 2007 , the average compound annual growth rate was about $24 \%$ [2]. In short, more and more people are willing to make purchases online. It is obvious that the online shopping market continues to grow, both domestically and abroad.

Currently, the largest online consumer group is still young people. However, thanks to advances in medical science, human beings are living longer, but this also means that the percentage of the population that suffers from the disabilities associated with aging increases year by year. This change in population structure has left us with the problem of a graying population, a problem being faced in all countries. This critical issue should not be disregarded in product design, the design of interactive interfaces and in the learning of information technology $[18,22]$. For obvious reasons, the elderly are often handicapped with inferior computer skills compared to those of younger people. Even so, online transactions could become an important shopping channel for this segment of the population. This trend is already evident, as shown by the increasing proportion of online shoppers drawn from the middle-aged or older sections of the population. According to one survey [30], the ratio of middle-aged and older online shoppers increased by about 4-5 percent between 2002 and 2003. Furthermore, the number of Internet consumers over 50 years old grew from $2 \%$ to $5 \%$ between 2003 and 2005. These are early indicators of the potential of the aging online shopping population. Therefore, future growth of online consumption is still expected, among consumers of all ages. Designing a better shopping environment for the young and the elderly has become an important issue that should not be disregarded.

Recently, research on consumer online behavior, such as the convenience of web based commerce and customer intention to return online, has been increasing. In Koufaris et al.'s study [9] of consumer behavior in web-based commerce, they found that perceived control and shopping enjoyment can increase the intention of new web customers to return, but do not seem to influence customers to return. They also found that a Web store that utilizes value-added search mechanisms and presents a positively challenging experience can increase customer shopping enjoyment. In 2005, Wells et al. [29] noted that consumer interfaces design is important for experiential tasks. They found that an interface based upon the business domain metaphor stimulated higher levels of retention and recall of information and thus provided the desired support for experiential tasks. Further, users with weaker domain familiarity showed the greatest improvement in retention and recall, particularly after a 2-day lag, when using the interface with the business domain metaphor design. Garrity et al. [6] examined the success of web-based information systems (WIS) focusing on user satisfaction in the context of consumer purchasing decisions. Their results indicated strong support for a research model consisting of three fun- damental user satisfaction components: task support satisfaction (TSS); decision support satisfaction (DSS) and interface satisfaction. In 2007, Ozok et al. [21] proposed the concept of impact of consistency in customer relationship management on E-commerce shopper preferences. They indicated that the technical factor included consistency of shopping steps, site design and navigation, while the customer treatment factor included consistency of promotions, in-stock indication, product variety, fraud protection, presented guarantees, customer fairness and return policies.

Although the e-commerce market is developing so rapidly, unpleasant experiences with online shopping are still common. The reasons given for the big difference between the number of visitors or browsers and actual purchasing customers include the following: 1) consumers felt that the online shopping procedure was too complicated; 2) there was too much unnecessary information provided on the website; 3) the web pages were not properly designed to facilitate the interactive interface [10-11, 15, 28]. Additionally, surveys show that Internet user satisfaction for online shopping dropped from $79 \%$ in 2001 to $60 \%$ in 2005 [3]. This is because, as consumers attach more importance to online shopping, their requirements are getting higher. There are many reasons why consumers may feel unsatisfied. Besides transaction security, unknown product quality, and unclear shopping procedures, dissatisfaction is also directly related to the inability to obtain information on par with that given when shopping in the real world, where one can actually touch products. Previous studies also show that most middle-aged and older individuals do not derive much benefit from advancements in technology. The main reason is the frustration caused by difficulties encountered when using websites. It is common for the middle-aged and elderly to be somewhat intimidated by using new technology and equipment designed for convenience. This sense of fear is often acerbated by difficulties they have encountered in the past.

Online shopping can be looked at as a process consisting of a series of human-computer interactions and decision-making behaviors. In this process, consumers have to make decisions based on a huge amount of product information, evaluation and comparison, and different options. Huang [8] argues that the information load that consumers receive during the process of online shopping process is often much higher than that received during traditional shopping. The huge amount and variety of information can pose a challenge to the consumer's information processing ability, which in turn affects their intention towards browsing or purchasing. Website designers should takes the information load into account, coming up with better interactive and more helpful interface designs that will give consumers a more pleasant, more convenient shopping environment. If too much complex information is provided, potential customers might leave and never come back. This would be a big loss to the online outlet. To attract customers, the online store first needs to understand the behavior of their shoppers as well as the difficulties that could occur 
during the purchasing procedure. They need to provide a well-designed interactive interface along with an improved shopping procedure that offers the shopper a convenient transacttion process, together with a pleasant shopping experience. This is the best way to encourage the consumer's purchasing intention, and attract return business [5, 26].

From the above, it can be seen that the two most important factors that impact the customer's intention to complete the online shopping procedure are the complexity of the operation and the design of the website interface. We next discuss the behavioral steps of online shopping using an Internet consumer behavior model to delineate the structure. We also evaluate the present condition of information and user interface design of both domestic and foreign shopping websites, trying to understand the effect of the information content and related supportive user interface design for websites selling different products. The aim is to provide website designers and owners with reference for designing better user interfaces, and hopefully, to reduce potential barriers consumers may encounter while shopping online.

\section{THE TRANSCEIVER STRUCTURE}

\section{Internet Consumer Behavior Model and Difficulties Encountered}

Duffy and Dale [5] found 10 factors which can critically affect the success of e-commerce. One of these is understanding customer behavior. This knowledge not only has an effect on decision-making related to the buying of the products, but can also help the retailer penetrate to the core of online marketing problems. Entrepreneurs and producers have to pay attention to the information they are giving to the customer and the difficulties experienced by the customer. Helping the consumer overcome these difficulties can facilitate the making of successful marketing decisions.

Some researchers have focused exclusively on younger age groups rather than the more mature and aging population [27]. O'Keefe and Mceachern [20] studied the traditional consumption behavioral process. They proposed that the decisionmaking process for online consumption included five steps: validation of needs; searching for information; evaluation; purchasing; and post-purchase assessment. Guttman et al. [7] however, divided consumer behaviors into six steps: need affirmation; product selection; finding retailers; negotiation; purchasing and delivery; and post-service assessment. Liang and Huang [17], based on the trading cost model, partitioned the online consumption process into eight steps: searching; comparison; examination; negotiation; ordering and payment; delivery; and post-service. Miles et al. [19] emphasized the importance of three activities in online shopping: management of product searches; search criteria; and comparison of searchable products.

Wang et al. [27] utilized observational methods to arrive at a ten-step online shopping behavioral model (the so-called ten-step model). This has been recognized as a more system-

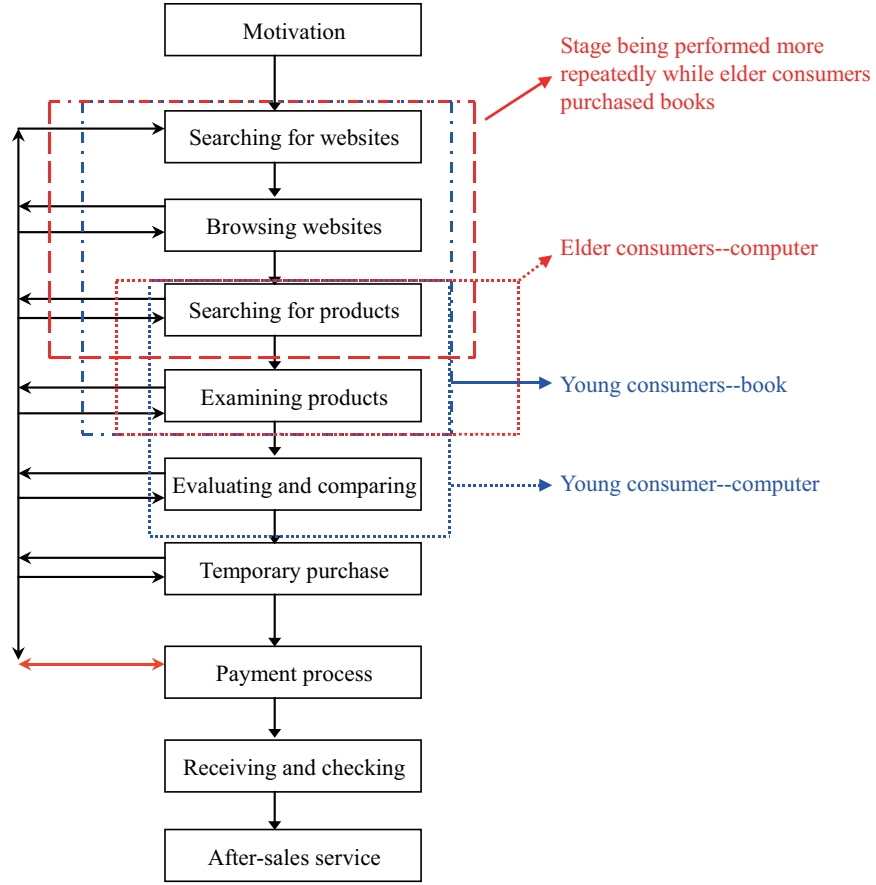

Fig. 1. B2C consumer behavior model for younger and older consumer groups.

atic and comprehensive behavioral model of the online shopper. Their model included the following: motivation; website searching; website browsing; product searches; product examination; comparison and evaluation; temporary orders; payment procedures; waiting for delivery; and post-service. It has been found that the reaction of the consumer to each step differs depending on the type of merchandise. For instance, when the item being purchased is a computer, consumers are willing to repeat the product search, product examination, and evaluation and comparison procedures; however, when buying books, the focus is on finding a lower price, so the related procedures include: searching for websites, browsing websites, product searches, and product examination.

Kuo [12] used the 10-step model as the basis for understanding the behavior of older subjects. They used observations and a behavior analysis software package to model the behavior of the aged Internet consumers but this is a rare example among current studies. They found, through this process of observation and analysis, that the behavior of online shoppers was greatly influenced by the website design and interactive mechanisms (which guided the consumers), while there is no big difference between interactive designs used between the website and the consumers. The behaviors exhibited by subjects were very similar regardless of age, namely, most tended to follow the ten-step model while completing the online shopping procedure, without the addition of any other behavioral step. However, there was a difference in the purchasing process between the age groups (Fig. 1). When purchasing books, older consumers repeated the product search, website search, and website browsing steps more often; when 
Table 1. Difficulties encountered by consumers in all steps of the purchasing process.

\begin{tabular}{|c|c|c|}
\hline Steps & Number & Types of difficulties encountered \\
\hline Searching for websites & $\begin{array}{l}1 \\
2\end{array}$ & $\begin{array}{l}\text { Do not know how to find a shopping website. } \\
\text { After entering keywords, too many similar websites are found making it difficult to decide } \\
\text { which one is more suitable. }\end{array}$ \\
\hline Browsing websites & $\begin{array}{l}1 \\
2 \\
3 \\
4\end{array}$ & $\begin{array}{l}\text { Too much information on the web page. } \\
\text { Information layout is not systematic, making it hard to understand and browse the pages. } \\
\text { Too many ads on the website. They create confusion and cause antipathy. } \\
\text { After spending a lot of time surfing a website, the customer finally finds out that there is no } \\
\text { purchase function (information provided). }\end{array}$ \\
\hline Searching for products & $\begin{array}{l}1 \\
2\end{array}$ & $\begin{array}{l}\text { Product categorization is complex and hard to understand which causes trouble when searching. } \\
\text { There are only limited search methods available meaning that the customer's product search } \\
\text { constraints cannot be met in a short period of time. }\end{array}$ \\
\hline Examining products & $\begin{array}{l}1 \\
2 \\
3\end{array}$ & $\begin{array}{l}\text { Product information is not sufficient or not what the customer wants. } \\
\text { Product-related pictures are not available so that customers can not be sure if the products are } \\
\text { exactly what they want. } \\
\text { The fonts used on the web page are too small making it difficult to browse or read. }\end{array}$ \\
\hline Evaluating and comparing & $\begin{array}{l}1 \\
2 \\
3\end{array}$ & $\begin{array}{l}\text { Price formats are inconsistent making it hard to make a comparison. } \\
\text { Information cannot be organized together for comparison. This can only be done by switching } \\
\text { between pages or writing down the prices. } \\
\text { The customer needs to remember a lot of information making the mental workload too heavy. }\end{array}$ \\
\hline Temporary purchase & $\begin{array}{l}1 \\
2\end{array}$ & $\begin{array}{l}\text { Hard to change the quantity of product purchased. } \\
\text { Icons (such as shopping carts) are too small to be found right away. }\end{array}$ \\
\hline Payment process & $\begin{array}{l}1 \\
2 \\
3 \\
4 \\
5\end{array}$ & $\begin{array}{l}\text { Non-members must become members to make purchases. } \\
\text { Related links (such as "register" and "pay") are hard to find. } \\
\text { Related information is hard to revise. } \\
\text { Payment procedure is too complex. } \\
\text { Older customers' typing speed may be slow but there is a lot of information that needs to be } \\
\text { keyed in when making payments. } \\
\text { Not enough choices of input method. (For example, using drop-down menus or handwriting } \\
\text { input methods). }\end{array}$ \\
\hline
\end{tabular}

purchasing notebook computers, older consumers repeated the product search and product examination steps more often. On the other hand, the older consumer (perhaps having more monetary resources) repeated the evaluation and comparison steps fewer times than the younger consumer did. Aged consumers found the payment procedure to be the most time consuming part of the process when buying books (30.6\%). Membership registration took nearly half $(62.4 \%)$ of the overall payment procedure time. At least $33 \%$ of the time was spent reviewing instructions related to the payment and purchase procedures, with older consumers spending more time on these two steps than the younger group do. The second highest amount of time was spent on the website search procedure $(20.3 \%)$. During the notebook computer purchasing process, however, most time was spent on the product examination step (39.2\%), with function examination taking the majority of that time. The next lengthiest procedures were the product search $(19.4 \%)$ and payment procedures (15.8\%), with membership registration taking about $72.2 \%$ of the payment procedure time. These results demonstrate that the older group was slower at inputting and reading information than the younger group was. Furthermore, they had more difficulty searching for products, needing to spend more time to find the websites and products they wanted than the younger group did. On the other hand, the older consumers spent a smaller percentage of time $(3.4 \%)$ on the "evaluation and comparison" step than the younger consumers $(9.3 \%)$ did. This is likely because they have more disposable income, so can respond much quicker during the product comparison and decision-making procedures than the younger population can [10-11].

It is very important when trying to attract and retain Internet consumers, to understand and anticipate any difficulties they might encounter during the shopping process and to solve or eliminate these through better website interface design [13]. Kuo et al. [10-11] developed a behavioral model of the Internet shopping consumers based upon observations and structured interview methods. Possible difficulties encountered when purchasing online are listed in Table 1. The degree of severity encountered when purchasing different products is indicated in Table 2. We observe that consumers encounter very serious difficulties in some steps.

\section{Website Information and User Support Interface Design}

In the process of online shopping, consumers are asked to make decisions, evaluations and comparisons from a huge 
Table 2. Degree of severity of difficulties encountered when purchasing different products.

\begin{tabular}{|c|c|c|c|}
\hline \multirow{2}{*}{ Purchasing step } & \multirow{2}{*}{ Difficulty number } & \multicolumn{2}{|c|}{ Degree of severity } \\
\hline & & Book & Computer \\
\hline \multirow{2}{*}{ Searching for websites } & 1 & very serious & mild \\
\hline & 2 & Serious & very serious \\
\hline \multirow{4}{*}{ Browsing websites } & 1 & Serious & very serious \\
\hline & 2 & very serious & serious \\
\hline & 3 & serious & very serious \\
\hline & 4 & mild & mild \\
\hline \multirow{2}{*}{ Searching for products } & 1 & serious & serious \\
\hline & 2 & very serious & serious \\
\hline \multirow{3}{*}{ Examining products } & 1 & very serious & serious \\
\hline & 2 & very serious & very serious \\
\hline & 3 & mild & mild \\
\hline \multirow{3}{*}{ Evaluating and comparing } & 1 & mild & very serious \\
\hline & 2 & serious & very serious \\
\hline & 3 & serious & very serious \\
\hline \multirow{2}{*}{ Temporary purchasing } & 1 & mild & mild \\
\hline & 2 & serious & mild \\
\hline \multirow{6}{*}{ Payment process } & 1 & very serious & very serious \\
\hline & 2 & mild & mild \\
\hline & 3 & mild & mild \\
\hline & 4 & mild & mild \\
\hline & 5 & very serious & serious \\
\hline & 6 & serious & serious \\
\hline
\end{tabular}

amount of product information for a large variety of options. Huang [8] suggests that the information load received by the consumers is much higher in the online shopping process than the traditional shopping process. The customer's information processing ability can be challenged by the huge amount and variety of information, which will affect their intention of browsing or purchasing.

The Human-Computer Interface (HCI) is an interface channel and an environment for information exchange between users and computers. The design of the HCI can have a substantial impact on learning time, performance speed, error rates and user satisfaction. Commercial designers recognize that systems that are easier to use will have a competitive edge in terms of information retrieval, office automation, and personal computing applications $[16,24]$. In the process of online consumption, the most important interface design issue is the design to the website. According to Dalal et al. [4] the current problems caused by design errors in complex websites are overemphasis on multimedia presentation, irregular and meaningless links, and inharmonious web pages with a lack of information prompts. All these features can cause inconvenience and disturbance to the users. In this study, it is also pointed out that although there are some reference standards for website design available at the present time, most of these are based on the designers' personal instinct and general knowledge. There is a lack of standards based on perception and there are not many theoretical or experimental verification studies. This is why we verify our results by experiments. The results show that websites designed following the interface design standards are easier for the user to comprehend, and take less of their time.

Trappey et al. [26] examined online stores, providing a set of standard elements describing general user interfaces and contents. Through the combination of these standard elements, the advantages and disadvantages of websites can be evaluated and compared. In this study, we carry out statistical analysis of each element's distribution in several popular global websites. The results show that there is a significant difference in the distributions of some elements. With these and the inferences obtained from other statistical analyses, online stores can be re-designed to form prototypes for successful websites.

Miles et al. [19] looked at current websites from the Internet consumer's point of view, suggested ways to design the interactions in a more consumer-friendly way using hierarchical arrangements, hyperlinks, electronic sales assistants, text-based pages and 3D virtual environments. Examples of websites which provide consumers better support and those with ill-designed interactions were mentioned as references for website design. Kuo et al. [14] evaluated 238 domestic and foreign shopping websites offering products from 5 categories: computer equipment, books, cell phones, tickets and flowers. After reviewing the condition information and user interface design for each of the websites, they found there to be a significant difference in the information and user inter- 
faces provided by the websites in each shopping step. Of these, the worst condition was for the "evaluating and comparing" step. The information and user interfaces provided by online book stores were more complete than websites selling tickets and flowers did. As for the overall differences between domestic and foreign websites, they found the information content and user interfaces provided by domestic websites are more complete (especially those selling tickets and flowers) than foreign ones. On the other hand, they found domestic websites for online computer sellers are less complete than foreign ones. The duration of website data evaluated was from Oct. - Dec., 2002, which is 6 years ago. Best selling products, website information and interface design change rapidly with time, meaning that the conditions of website information and user interface design are now quite different.

Kuo et al. [15] examined computer product shopping websites. They then designed user interfaces aimed at young people for the "examining products" and "evaluating and comparing" steps. The user interface helps the consumer to view and evaluate products and reduces the mental workload during the online shopping process. In this study, objective and subjective measurement indexes are used in observation experiments to evaluate the effectiveness of these interfaces. The results show that the design of the supporting user interface can actually help young consumers to view, evaluate and compare product information. For subjects with different shopping experience, the effectiveness of the support in the "product examination" and "evaluating and comparing" steps are also different.

Consumer demands for a better online shopping environment are getting harder to meet. Customers are paying much attention to the information and user interface design provided by websites. Providing the appropriate amount of information and well-designed user interface is important for the consumer especially for the older consumer, as it could go a long way towards helping them overcome their difficulties and fear.

\section{RESEARCH METHODOLOGY}

We now discuss the behavior model on which this study is based. The present information offered on the website and user interface designs of several domestic and foreign shopping website were evaluated. The goal is to attain an understanding of current conditions to be used as reference for design improvements leading to a more convenient shopping environment in the future.

A ten step Internet consumer behavior model forms the basic structure of the evaluation. Numerous websites selling different kinds of products were browsed, and their contents and user interfaces analyzed. The conclusions and results were organized with the content analysis method. After referencing related documents [14] an information and user interface for shopping websites evaluation form was designed. The content can be divided into two parts, the header and the evaluation content. The header includes basic information
Table 3. Distribution of the 351 websites.

\begin{tabular}{|l|c|c|c|}
\hline \multicolumn{1}{|c|}{ Domestic or Foreign } & Domestic & Foreign & Sum \\
\hline Product Category & 30 & 20 & 50 \\
\hline Bomputers & 30 & 20 & 50 \\
\hline Cell Phones & 30 & 20 & 50 \\
\hline Tickets & 30 & 20 & 50 \\
\hline Flowers & 30 & 20 & 50 \\
\hline Traveling Products & 30 & 20 & 50 \\
\hline Beauty Products & 31 & 20 & 51 \\
\hline Sum & 211 & 140 & 351 \\
\hline
\end{tabular}

such as website title, URL and products for sale. The evaluation content includes five fields: behavioral steps, evaluation items, descriptions of the items, reference graphs, and evaluation results.

It is found from related survey data that books, computers, beauty products, travel products, cell phones, tickets and flowers are the products most commonly selected by Internet users. These products also served as evaluation subjects in this study. After the evaluation form was designed, three experts familiar with shopping websites and human-computer interface methods were asked to evaluate domestic and foreign shopping websites offering products from seven different categories: books, computers, beauty products, travel products, cell phones, tickets and flowers. The websites were selected for evaluation by random sampling. The evaluators determined whether the information content or user interface as described in each evaluation item fits the condition of the website following the behavioral steps on the left (from "motivation", "searching for websites", "browsing websites" to "payment process" and "after-sales service"). If the information or user interface design fits the condition of the evaluated website, evaluators would check "yes" in the evaluation result field. If not, they would check "no". If the description was not adequate, they would check "not adequate" in that field. 351 shopping websites were evaluated.

After the results were recorded and organized, the percentage of websites which were judged to contain the appropriate information or user interface as described by the specific evaluation item were calculated. This helped us to understand each website's condition in relation to these two aspects. Then, the behavioral step, product category, differences between domestic/foreign websites, differences between product category (books, computers, beauty products, traveling products, cell phones, tickets, and flowers) and the ten shopping steps was analyzed. The results are discussed below.

\section{DATA COLLECTION AND ANALYSIS}

The product distributions for the 351 websites are listed in Table 3. The evaluation results for the present conditions (information and user interface design) are given in Appendix 1. 
Table 4. Results organized by product category and behavioral step (\%).

\begin{tabular}{|c|c|c|c|c|c|c|c|c|}
\hline $\begin{array}{ll}\text { Behavioral step } & \text { Product category } \\
\end{array}$ & Computers & Books & Cell phones & Tickets & Flowers & $\begin{array}{l}\text { Traveling } \\
\text { Products }\end{array}$ & $\begin{array}{c}\text { Beauty } \\
\text { Products }\end{array}$ & Average \\
\hline Motivation & 41 & 35 & 38 & 27 & 27 & 29 & 39 & 33.5 \\
\hline Searching for websites & 57 & 45 & 58 & 38 & 43 & 51 & 53 & 49.3 \\
\hline Browsing websites & 76 & 69 & 73 & 47 & 51 & 51 & 69 & 61.9 \\
\hline Searching for products & 58 & 61 & 55 & 45 & 43 & 45 & 54 & 51.5 \\
\hline Examining products & 88 & 78 & 90 & 71 & 76 & 84 & 85 & 81.9 \\
\hline Evaluating and comparing & 57 & 53 & 52 & 17 & 21 & 34 & 39 & 38.8 \\
\hline Temporary purchasing & 86 & 90 & 84 & 55 & 77 & 47 & 91 & 75.4 \\
\hline Payment process & 60 & 57 & 53 & 44 & 58 & 42 & 66 & 54.0 \\
\hline Receiving and checking & 65 & 60 & 63 & 48 & 61 & 45 & 69 & 58.6 \\
\hline After-sales service & 85 & 86 & 80 & 68 & 75 & 67 & 86 & 78.2 \\
\hline Average & 69.5 & 66.6 & 66.5 & 48.9 & 55.6 & 51.9 & 67.6 & \\
\hline
\end{tabular}

Table 5. Test of differences between each two products.

\begin{tabular}{|c|c|c|c|c|c|c|}
\hline & Books & Cell phones & Tickets & Flowers & Traveling & Beauty \\
\hline Computers & $2.109^{*}$ & $2.181^{*}$ & $14.214^{*}$ & $9.739^{*}$ & $12.220^{*}$ & 1.394 \\
\hline Books & & 0.079 & $12.152^{*}$ & $7.652^{*}$ & $10.145^{*}$ & -0.725 \\
\hline Cell phones & & & $12.081^{*}$ & $7.580^{*}$ & $10.074^{*}$ & -0.798 \\
\hline Tickets & & & & $-4.549 *$ & $-2.035^{*}$ & $-12.927^{*}$ \\
\hline Flowers & & & & & $2.517^{*}$ & $-8.411^{*}$ \\
\hline Traveling & & & & & & $-10.914^{*}$ \\
\hline
\end{tabular}

Note: * Significantly different (95\% confidence coefficient).

The numbers in the table represent the percentage of websites providing the appropriate information or user interface design related to the evaluation item for websites which sell that product. For example, among domestic websites selling books, $67 \%$ periodically emailed their members product promotion-related information (first item of the "Motivation" step), while $95 \%$ of foreign websites did so. The basic features of website evaluation (by product category, behavioral step, and domestic/foreign websites) and supporting user interface design system are described below.

Product categories and behavioral steps, as organized in Appendix 1, are shown in Table 4. The average overall percentage of websites (for all seven product categories) which provide adequate information and supportive user interface design (in relation to each evaluation item) can be found in the last row of table 4 . Of these websites, those selling computers have the highest percentage $(69.5 \%)$ for providing information or user interface design. This is followed by websites selling beauty products $(67.6 \%)$, those selling books and cell phones (over 66\%), and those selling flowers, travel products, and tickets (all with less than 60\%). The worst performance was for websites selling tickets, with an average percentage of only $48.9 \%$. Furthermore, we may note that the difference of percent between each two products was shown in Table 5. Most of the differences are highly significant (95 percent confidence coefficient).

The evaluation results (organized according to behavioral steps) are listed in the last column of Table 4. Among these steps, "Examining products" has the highest evaluation value $(81.9 \%)$, which means that the information and user interface design in the purchasing process is provided by the "product examination" step. The second and third best are the "after-sales service" and "temporary purchase" steps, with percentages of $78.2 \%$ and $75.4 \%$, respectively. The "searching for products" step gets $61.9 \%$. The evaluation results for all of the other six steps are less than $60 \%$. Of these steps, the worst evaluations are "evaluating and comparing" and "motivation" steps, with percentages of $38.8 \%$ and $33.5 \%$, respectively. The results show that the website information and user interface design is still not sufficient to motivate customers to buy, or to help them evaluate and compare products. While considering the significant difference between each two behavioral steps, Table 6 showed the results. Almost of the differences are highly significant.

We now compare information and user interface design offered by domestic/foreign websites. On average, foreign websites $(65.6 \%)$ performed better than domestic websites $(57.5 \%)$. Data were further subdivided according to product categories. Differences are shown in Fig. 2. The test of difference between domestic and foreign websites was shown in 
Table 6. Test of difference between each two processes.

\begin{tabular}{|c|c|c|c|c|c|c|c|c|c|}
\hline Process & $\begin{array}{c}\text { Searching } \\
\text { for websites }\end{array}$ & $\begin{array}{l}\text { Browsing } \\
\text { websites }\end{array}$ & $\begin{array}{l}\text { Searching } \\
\text { for products }\end{array}$ & $\begin{array}{l}\text { Examining } \\
\text { products }\end{array}$ & $\begin{array}{c}\text { Evaluating } \\
\text { and } \\
\text { comparing }\end{array}$ & $\begin{array}{l}\text { Temporary } \\
\text { purchasing }\end{array}$ & $\begin{array}{l}\text { Payment } \\
\text { process }\end{array}$ & $\begin{array}{l}\text { Receiving } \\
\text { and } \\
\text { checking }\end{array}$ & $\begin{array}{c}\text { After-sales } \\
\text { service }\end{array}$ \\
\hline Motivation & $-7.016^{*}$ & $-15.065^{*}$ & $-10.816^{*}$ & $-27.638^{*}$ & $-2.923 *$ & $-22.292 *$ & $-10.949 *$ & $-12.396^{*}$ & $-29.114^{*}$ \\
\hline $\begin{array}{c}\text { Searching } \\
\text { for websites }\end{array}$ & & $-5.517^{*}$ & -1.028 & $-16.365^{*}$ & $4.598^{*}$ & $-11.981 *$ & $-2.036^{*}$ & $-3.836^{*}$ & $-15.591 *$ \\
\hline $\begin{array}{l}\text { Browsing } \\
\text { websites }\end{array}$ & & & $6.252 *$ & $-12.583 *$ & $12.241 *$ & $-7.710 *$ & $4.240 *$ & 1.656 & $-11.472 *$ \\
\hline $\begin{array}{l}\text { Searching } \\
\text { for products }\end{array}$ & & & & $-20.285^{*}$ & $7.607 *$ & $-14.594^{*}$ & -1.496 & $-3.865^{*}$ & $-21.033^{*}$ \\
\hline $\begin{array}{l}\text { Examining } \\
\text { products }\end{array}$ & & & & & $24.897 *$ & $4.458^{*}$ & $16.924 *$ & $13.489 *$ & $3.080^{*}$ \\
\hline $\begin{array}{c}\text { Evaluating and } \\
\text { comparing }\end{array}$ & & & & & & $-19.593^{*}$ & $-8.076^{*}$ & $-9.728 *$ & $-25.945^{*}$ \\
\hline $\begin{array}{l}\text { Temporary } \\
\text { purchasing }\end{array}$ & & & & & & & $11.864 *$ & $8.849^{*}$ & $-2.085^{*}$ \\
\hline $\begin{array}{l}\text { Payment } \\
\text { process }\end{array}$ & & & & & & & & $-2.273^{*}$ & $-16.586^{*}$ \\
\hline $\begin{array}{l}\text { Receiving and } \\
\text { checking }\end{array}$ & & & & & & & & & $-12.451^{*}$ \\
\hline
\end{tabular}

Note: * Significantly different (95\% confidence coefficient).

Table 7. Evaluation results (\%) and test of differences between domestic and foreign websites.

\begin{tabular}{|c|l|l|l|l|l|l|l|l|}
\hline & Computers & Books & Cell phones & Tickets & Flowers & Traveling & Beauty & Average \\
\hline Domestic & 68.5 & 65.3 & 64.0 & 42.9 & 51.8 & 45.4 & 64.6 & 57.5 \\
\hline Foreign & 70.3 & 67.7 & 69.6 & 57.9 & 60.9 & 61.4 & 71.4 & 65.6 \\
\hline Difference test & -0.916 & -1.193 & $-2.782^{*}$ & $-7.050^{*}$ & $-4.302^{*}$ & $-7.523^{*}$ & $-3.406^{*}$ & $-3.897 *$ \\
\hline
\end{tabular}

Note: * Significantly different (95\% confidence coefficient).

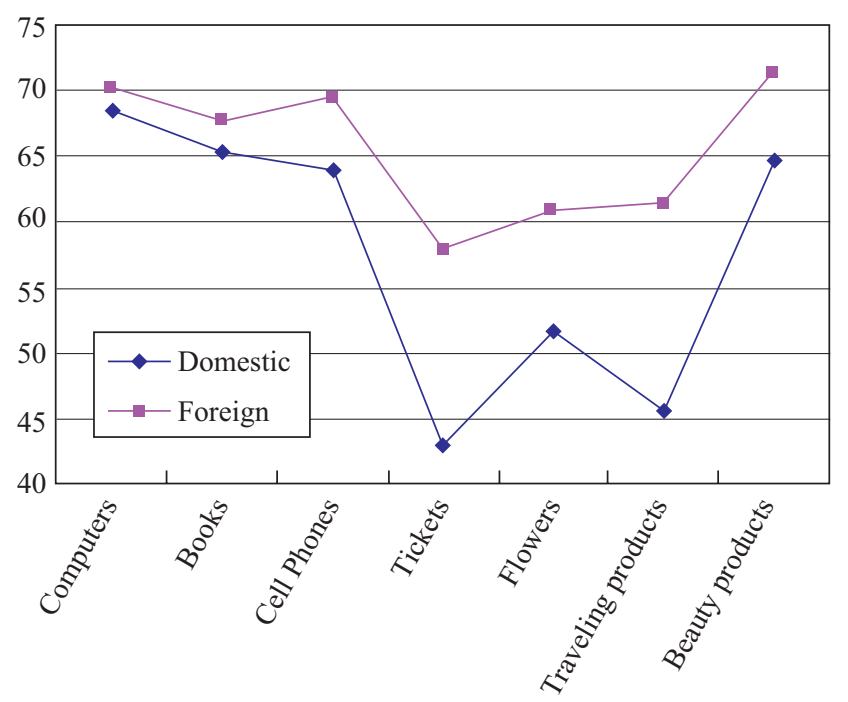

Fig. 2. Comparison of domestic and foreign websites by product category.
Table 7. It can be seen that foreign shopping websites selling travel products, flowers and tickets offered better information and user interface conditions than domestic websites did. Foreign websites selling cell phones, books, computers and beauty products also did better than domestic websites. Beside computers and books, the other products were highly significant. The data are further sub-divided according to the ten behavioral steps. The differences are plotted in Fig. 3. Foreign websites performed better in the "browsing website", "searching for website", "searching for products" and "aftersales service" steps, while domestic websites performed significantly better than foreign websites did only for the "examining products" step. The differences for other steps were rather small.

Although the overall evaluation results showed that foreign websites performed better than domestic websites did, further study of each evaluation item, showed that domestic websites performed better for some items (see Appendix 1). For example, for the "map of stores for purchase pick-up" item in the 


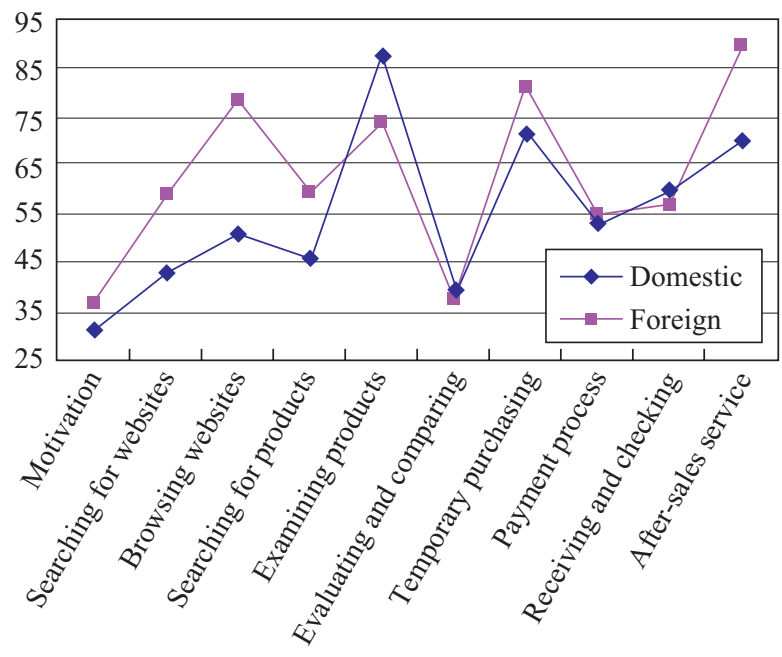

Fig. 3. Differences between domestic and foreign websites by behavioral step.

"payment process" step, $27 \%$ of domestic websites selling computers and books provided such information to customers. This percentage was higher than foreign websites $(5 \%$ for books, $0 \%$ for computers). For the "dynamic presentation" item in the "examining products" step, $93 \%$ of domestic websites selling computers presented some product information dynamically, while only $45 \%$ of foreign websites did. For the "active notification via SMS" item in the "receiving and checking" step, $30 \%$ of domestic websites selling computers notified their customers of order and delivery status via SMS, while only $5 \%$ of the foreign websites did. It can be seen in appendix 1 that domestic websites still did better than foreign website did at providing adequate information and user interface design for some items.

\section{EVALUATION RESULTS OF INFORMATION AND USER INTERFACE DESIGN FOR WEBSITES}

Inputting customer information when making payments or inputting basic information when registering is a necessary and important part of the online shopping process. The website evaluation results show that almost all foreign websites (no matter what kinds of products they sell) require customers to have memberships or provide member registration services. With the exception of those selling tickets and travel products, all domestic websites provide member registration services and over $80 \%$ of them require membership to make purchases. A lot of information must be input for websites providing member registration services or requiring memberships. The most common input method is keying-in. Only a few fields could be input with drop-down lists.

What information is required when registering for an account? Results of survey analysis shows that with the exception of ticket selling websites, more than half of them require an account ID, password, password confirmation, name, ID, email address, phone number, detailed address, birthday, nationality, zip code, etc. to complete registration. Some websites even require more information such as gender, marital status, tax ID, cell phone number, office phone number, company name, user ID, authentication code, occupation, education, income, password hint, where the applicant found out about the website, e-newspaper subscription, blood type, and so on. Inputting so much information can be a very complex process. Furthermore the most common input method is keying-in; only a few of the fields can be input using drop-down menu lists (for example, birthday was available on $60 \%$ of website; nationality on $60 \%$; zip code on $60 \%$ ), or "county", "city", "district" and "town" in the address field. For shoppers whose typing speed is very slow (especially aged shoppers) registering an account can be a very difficult task.

From related research results, it can be found that the abilities of searching, product examination and data input of the aged online shoppers are all lower than for young shoppers. When buying computer products with more complex functions, they often have to repeat the "searching for products" and "examining products" steps several times. They spend more time on "searching for products", "examining products", "payment process" and "evaluating and comparing". The degree of seriousness of most of the problems encountered in the "searching for products", "examining products" and "evaluating and comparing" steps is serious or very serious. At the present time, shopping websites does not provide sufficient information or adequate user interface designs for these steps. Therefore in the future, a more supportive type of user interface design system should be developed for the following steps: "searching for products", "examining products", "evaluating and comparing" and "payment process". Hopefully, the "searching for products", "examining products" and "evaluating and comparing" steps can be integrated, and ways provided to simplify data input interfaces in the "payment process" step (such as Fig. 4), to ultimately provide customers with easy-to-use shopping environments. We now discuss the case study of a support interface. After connecting to the website (Fig. 5, left-hand side), the consumer first sets up his search criteria (such as brand, price range, and required functions), then clicks the "search" button. Then a page (Fig. 6) will be presented with an organized table of information on the products satisfying those criteria. The consumer can browse through the products (more details about a certain product can be viewed by clicking on that product), evaluate them, and make comparisons. The products the customer does not want can be removed immediately by clicking the corresponding " $\mathrm{X}$ " buttons, making it easy to narrow down the range of his choices and reduce the amount of information, to finally find the product(s) he really wants to buy. This kind of design saves the time spent switching between pages. Consumers can easily compare product information on the same page. They do not need to memories so many prices and functions which lightens the information load. 


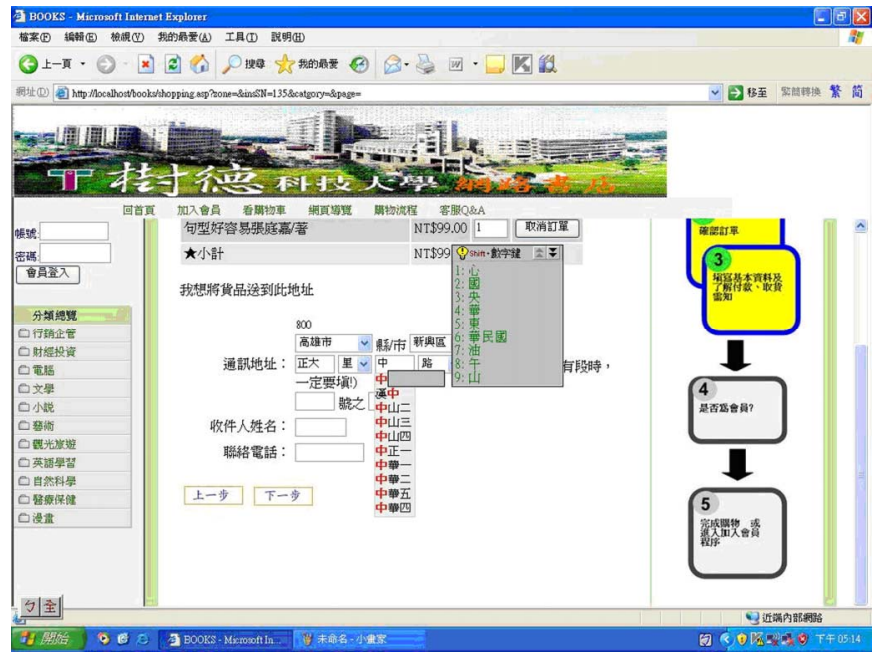

Fig. 4. Supporting interface design for the payment procedure page.

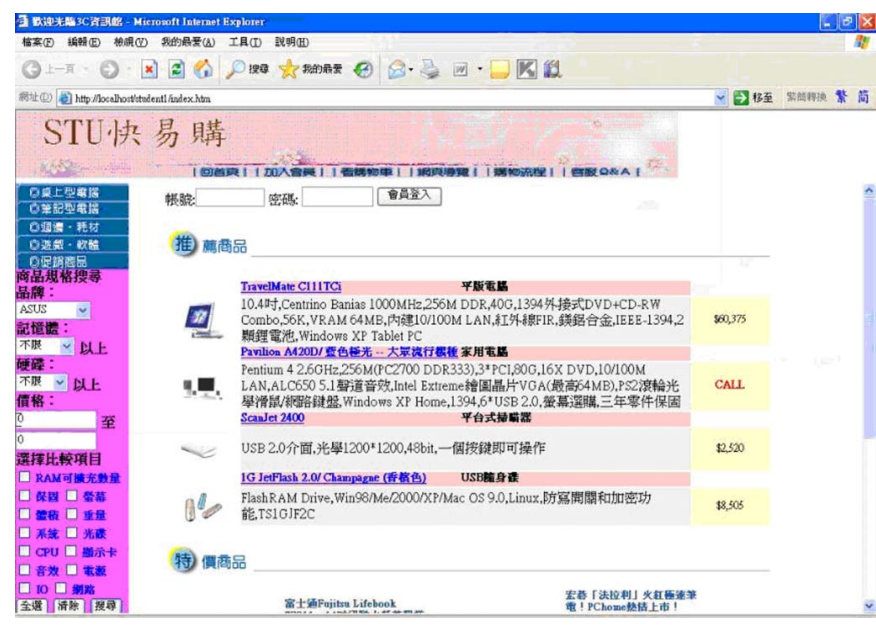

Fig. 5. Supporting interface design for the computer product search page.

\section{CONCLUSION}

The increasing popularity of online shopping has led to increasing demand by Internet users for better online shopping environments. This demand is getting harder to satisfy, especially when it comes to the issues of sufficient information, user-friendly interface design, and convenience of the online shopping process. The process is divided into a 10-step Internet consumer behavior model which serves as the basis of this study. Evaluations on the condition of two factors (website information and user interface design) were performed on domestic and foreign shopping websites. Comparisons were made between websites from the aspects of product category, behavioral step and domestic/foreign websites. The goal is to understand the conditions of supportive interface design of shopping websites. Finally, by referencing data related to customer situations, such as the repetition of some of the behavioral steps and difficulties users generally encounter, we can form some conception of how to improve future website

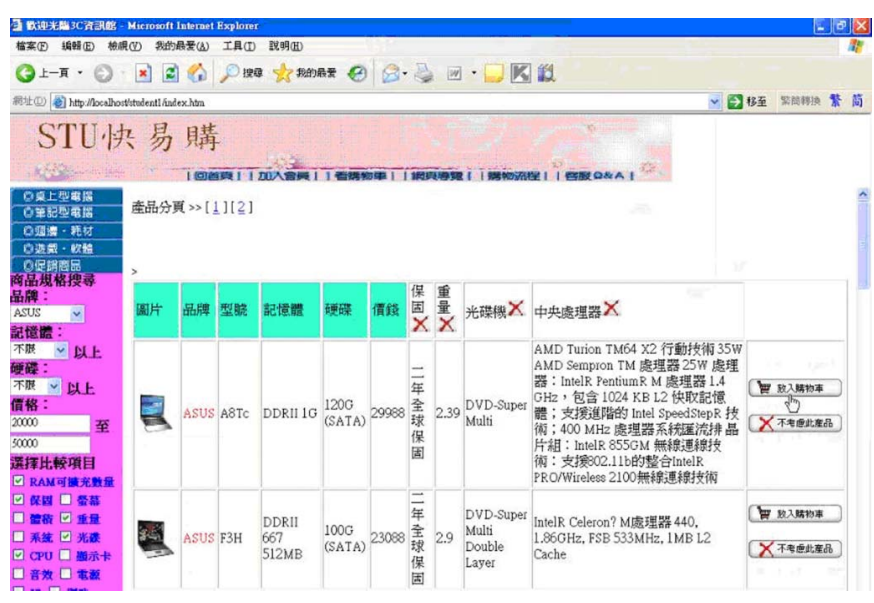

Fig. 6. Supporting interface design for the organized product search, preview and evaluation page for computer products.

information and interface design. This material can hopefully be useful as reference for both academic study and for online store management, to provide customers with a more convenient shopping environment.

\section{ACKNOWLEDGMENTS}

The authors would like to thank the National Science Council for financial support of this research under Contract No. NSC 96-2221-E-366-007- and NSC 98-2221-E-366-006-MY2. The authors are also most grateful for the kind assistance of Prof. Chee-Fai Yung, Editor-in-chief of Journal of Marine Science and Technology, and the constructive suggestions of the anonymous reviewers, all of which has led to the making of several corrections and suggestions that have greatly aided us in improving the presentation of this paper.

\section{REFERENCES}

1. Chen, H. I., Development Trends of the US Internet Shopping Market, Institute for Information Industry, Market Intelligence Center (2005a).

2. Chen, H. I., Development Trends of the Western Europe Internet Shopping Market, Institute for Information Industry, Market Intelligence Center (2005).

3. Chen, H. I. and Chou, S. L., 2005 Analysis on Taiwan Internet User Behavior, Institute for Information Industry, Market Intelligence Center (2005).

4. Dalal, N. P., Quible, Z., and Wyatt, K., "Cognitive design of home pages: an experimental study of comprehension on the World Wide Web," Information Processing and Management, Vol. 36, pp. 607-621 (2000).

5. Duffy, G. and Dale, B. G., "E-commerce processes: a study of criticality," Industrial Management and Data System, Vol. 102, No. 8, pp. 432-441 (2002).

6. Garrity, E. J., Glassberq, B., Kim, Y. J., Sanders, G. L., and Shin, S. K., "An experimental investigation of Web-based information systems success in the context of electronic commerce," Decision Support Systems, Vol. 39, No. 3, pp. 485-503 (2005).

7. Guttman, R. H., Moukas, A. G., and Maes, P., "Agent-mediated electronic commerce: a survey," Knowledge Engineering Review, Vol. 13, 147-159 (1998).

8. Huang, M. H., "Information load: its relationship to online exploratory 
and shopping behavior," International Journal of Information Management, Vol. 20, pp. 337-347 (2000).

9. Koufaris, M., Kambil, A., and Labarbera, P. A., "Consumer behavior in Web-based commerce: An empirical study," International Journal of Electronic Commerce, Vol. 6, No. 2, pp. 115-138 (2001)

10. Kuo, H. M., Fu, H. H., and Hsu, T. H., "A behavioral model of the elderly internet consumer," Taiwan Ergonomics Engineering 14th Conference (EST2007), Cho Yung University of Institute (2007a).

11. Kuo, H. M., Fu, H. H., and Hsu, T. H., "A behavioral model of the elderly internet consumer," Taiwan Ergonomics Engineering 14th Conference (EST2007), Cho Yung University of Institute (2007b).

12. Kuo, H. M. and Hsu, T. H., "A study of online consumption behavior model of elder population," Proceedings of CIIE Annual Conference, ID-39, Tunghai University (2006).

13. Kuo, H. M., Hwang, S. L., and Wang, E. M. Y., "A preliminary study of consumer behaviors in B2C," Communications of the IIMA, Vol. 2, No. 4 pp. 79-91 (2002).

14. Kuo, H. M., Hwang, S. L., and Wang, E. M. Y., "Evaluation research of information and supporting user interface in electronic commerce web site," Industrial Management and Data System, Vol. 104, No. 9, pp. 712721 (2004).

15. Kuo, H. M., Wang, M. Y., and Huang, S. L., "An observational study on troubles encountered by online consumers," Journal of Ergonomics Studies, Vol. 7, pp. 9-16 (2005).

16. Lee, C. R., Wei, P. S., Shi, Y. F., and Qiu, Z. Z., Human-Computer Interface Design, Published by National Open University (1998).

17. Liang, T. P. and Huang, J. S., "An empirical study on consumer acceptance of products in electronic markets: a transaction cost model," Decision Support Systems, Vol. 24, pp. 29-43 (1998)

18. Lu, P. H., The Influence of Elder to Electronic Shopping in Virtual Reality by Link Structure, Master Thesis, Department of Industrial Engineering and Management, I-Shou University, Taiwan (2003).

19. Miles, G. E., Howes, A., and Davies, A. J., "A framework for understanding human factors in web-based electronic commerce," International Journal of Human-Computer Studies, Vol. 52, pp. 131-163 (2000).
20. O'Keefe, R. M. and McEachern, T., "Web-based customer decision support system," Communications of the ACM, Vol. 41, No. 3, pp. 71-78 (1998).

21. Ozok, A. A., Denburger, K., and Salvendy, G., "Impact of consistency in customer relationship management on E-commerce shopper preferences," Journal of Organizational Computing and Electronic Commerce, Vol. 17, No. 4, pp. 283-309 (2007).

22. Pennathur, A., Sivasubramaniam, S., and Contreras, L. R., "Functional limitations in Mexican American elderly," International Journal of Industrial Ergonomics, Vol. 31, No. 1, pp. 41-50 (2003).

23. Shih, T. K., Chiu, C. F., Hsu, H. H., and Lin, F., "An integrated framework for recommendation systems in e-commerce," Industrial Management and Data System, Vol. 102, No. 8, pp. 417-431 (2002).

24. Shneiderman, B., Designing the User Interface: Strategies for Effective Human-Computer Interaction, Addison-Wesley Publishing Company, Reading, Massachusetts (1986).

25. Tang, S. H., "Study on the difficulties aged users encountered when using cell phones with mental model," National Science Council 1995 Project Reports, pp. 5-10 (2006).

26. Trappey, C. V., Trappey, A. J. C., and Chang, Y.-P., "Internet storefront reengineering using an element schema approach," Human Systems Management, Vol. 19, pp. 295-303 (2000).

27. Wang, E. M., Kuo, H. M., and Hwang, S. L., "A study of B2C consumer behavior model," Journal of the Chinese Institute of Industrial Engineers, Vol. 22, No. 5, pp. 379-391 (2005).

28. Wang, E. M., Wu, Z. X., and Kuo, H. M., "A study on the effectiveness of an Online Consumer Aiding System (OCAS)," In: Yi, S., Chen, X., and Yang, Y. (Eds.), Modern Industrial Engineering and Innovation in Enterprise Management, Proceedings of the 12th International Conference on Industrial Engineering and Engineering Management, China Machine Press: Beijing, China, pp. 694-698 (2005).

29. Wells, J. D., Fuerst, W. L., and Palmer, J. W., "Designing consumer interfaces for experiential tasks: an empirical investigation," European Journal of Information Systems, Vol. 14, No. 3, pp. 273-287 (2005).

30. Yam.com, http://survey.yam.com/ (2003). 